\title{
A imagem da palavra e a palavra da imagem: o conto fotográfico de Tércia Montenegro
}

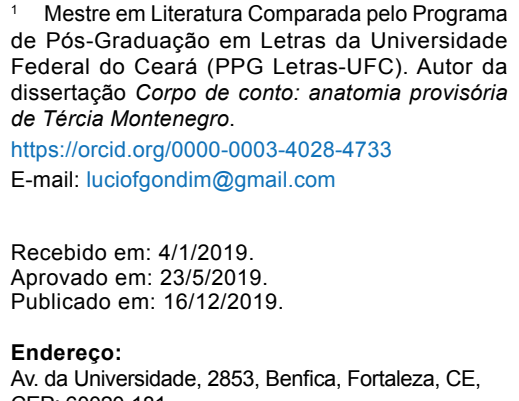

Endereço:

Av. da Universidade, 2853, Benfica, Fortaleza, CE,

Av. da: Universidade
The image of the word and the word of the image: the photographic tale of Tércia Montenegro

Lúcio Flávio Gondim da Silva ${ }^{1}$ Universidade Federal do Ceará, Fortaleza, CE, Brasil.

\section{RESUMO}

Ao longo de quase vinte anos de produção artística, Tércia Montenegro tensiona a relação entre palavra e imagem em seus contos, ensaios, livros infanto-juvenis e um romance. A partir especificamente da sua contística, observo neste artigo o que discute a autora ao dar ênfase ao caráter visual da literatura, em especial na relação das personagens com a fotografia. Em seus quatro livros de contos e em algumas participações em antologias, Montenegro desenvolve uma espécie de escrita fotográfica na qual corpos em seus desejos são apresentados de modo pictórico sem cair no naturalismo e sem perder a potência lírica. As fotografias agem, assim, como personagens nas narrativas, cruzando tempos e conflitando memória e finitude. Por fim, os humanos dos contos também são artistas da imagem e parecem perguntar: estou no dizível ou no visível?

Palavras-chave: Tércia Montenegro. Conto. Fotografia. Imagem. Palavra.

\section{ABSTRACT}

Throughout nearly twenty years of artistic production, Tércia Montenegro stresses the relationship between word and image in her short stories, essays, children's books, and a novel. Specifically, from her work, I observe in this article what the author discusses in emphasizing the visual character of literature, with an emphasis on the relation of the characters to photography. In his four short storybooks and some anthologies, Montenegro develops a kind of photographic writing in which bodies in his desires are presented pictorially without falling into naturalism and without losing the lyrical power. The photographs act thus as characters in the narratives, crossing times and conflicting memory and finitude. Finally, the humans of the tales are also artists of the image and seem to ask: Am I in the knowable or the visible?

Keywords: Terceira Montenegro. Tale. Photography. Image. Word. 


\section{A imagem da palavra}

$\mathrm{N}$ conto "A alma e o peso" do livro O tempo em estado sólido (2012), da escritora Tércia Montenegro, a narradora e protagonista confidencia aos seus leitores: "[...] persisto em deixar as fotografias dentro do envelope, numa gaveta. Imagino que elas têm uma temperatura fria [...]. Talvez chegue um momento em que eu possa folhear tais retratos como registros de meu rosto, apenas" (MONTENEGRO, 2012, p. 23). Nesse momento, a personagem dá uma pista emblemática. Ela fala do que parece querer dizer a grande presença de artistas, com seus registros estéticos, por meio, quase sempre, de expressões visuais, em especial, a fotografia, muito presente na obra de Montenegro. Nela, a imagem é um duplo, revelação visual sobre o nitrato de prata e, do mesmo modo, um esconderijo, segredo.

O corpo, sobremaneira, está em questão e, como no trecho do conto de Tércia Montenegro, parece se concentrar na face, aquela que captura imagem e vai ao encontro do rosto do outro, aquele que também me vê, mas que, fundamentalmente, é imaginário para mim. Por isso, a necessidade de esconder, pôr no fundo da gaveta, mentir, consciente de que, matando a fotografia, ela nunca morre, do contrário, resiste como um fantasma. Se penso a obra de um escritor por completo, o que seriam contos senão fotografias, bem como lembra Cortázar (2013)? E o que são as imagens para os contos que aqui analiso? Onde termina a fala do texto e começa a sua visão?

Levantando possíveis respostas, Alberto Manguel discute assim o ver e o dizer: "as narrativas existem no tempo, e as imagens, no espaço. [...] as palavras escritas fluem constantemente para além dos limites da página [...] As imagens, porém, se apresentam à nossa consciência instantaneamente, encerradas pela sua moldura" (MANGUEL, 2001, p. 24). Porém, as molduras aqui também se aparentam maleáveis. Nada está solidificado, assim como lembra Roland Barthes (1984, p. 13): "0 que a Fotografia reproduz ao infinito só ocorreu uma vez: ela repete-se mecanicamente o que nunca mais poderá repetir-se existencialmente". E quando há o acréscimo da palavra? Do escrito flui o imagético ou seria o contrário? Quem é mais imortal entre o que é dito e o que é visto?

Tércia Montenegro publicou o seu primeiro livro de contos em 1998, seguindo-o de publicações em 2001, 2005 e 2012, interligando-as sem conexão temática por participações em coletâneas com textos inéditos ou com inclusões de já publicados. A produção da cearense ganha, hoje, dimensão nacional graças às suas participações em coletâneas e antologias como 25 mulheres que estão fazendo a nova literatura brasileira (Record, 2004), Contos Cruéis: as narrativas mais violentas da literatura brasileira (Geração Editorial, 2005) e muitas outras, bem como pela publicação de seu primeiro romance, Turismo para Cegos (Companhia das Letras, 2015).

A escritora também é fotógrafa e já participou de algumas exposições individuais e coletivas. Em 2009, recebeu o prêmio de uma viagem à Bienal de Veneza 2009, pela XV Unifor Plástica, Salão de Artes da Universidade de Fortaleza. Em 2017 a fotografia "Laila e Pierre", homônima ao romance de estreia da escritora, pois nele inspirada, participou da Semana das Artes Visuais organizado pelo CLAV/IFCE e obteve o prêmio de primeiro lugar. A narrativa de Tércia Montenegro, interligada com diversas linguagens, visuais por excelência, pode ser entendida como (hiper)realista talvez na medida em que, nas palavras do professor e teórico Karl Erik Schøllhammer (2011), nelas

conjugam os temas da realidade social brasileira ao compromisso com a inovação das formas de expressão e das técnicas da escrita. Abrindo, desta maneira, caminho para um outro tipo de realismo, cuja realidade não se apoia na verossimilhança da descrição representativa, mas no efeito estético da leitura, que visa a envolver o leitor afetivamente na realidade da narrativa (SCHØLLHAMMER, 2011, p. 59).

Assim, a produção artística da autora mescla elementos da tradição e da contemporaneidade transgressora, tem momentos de descrição realista, mas tende mais ao poético. Não quebra formatos quanto à linearidade da marca textual, mas brinca com as temporalidades, mesclando memória e volição em muitos excertos. Tércia Montenegro aproxima e afasta o olhar do leitor em poucos parágrafos provocando o que, para ela, é a função artística por excelência: causar o estranhamento no leitor, "sobretudo porque as coisas para mim acontecem de modo tão sensato que (tirando algumas raras surrealidades) minha vida pode ser definida como banal. 0 espanto surge quando percebo que para muita gente a situação é diferente" (MONTENEGRO, 2012b, p. 27).

É fundamentalmente nos contos que a autora encontra em seu cotidiano o "que desloca o sujeito da sua percepção e atitude habituais e o retira dos limites 
do mundo conhecido" como fala César Guimarães (2006, p. 14) a respeito da experiência estética. É da imagem, entretanto, o poder central do seu ato narrativo. A visualidade aparece principalmente porque, em quase todos os momentos, sujeito e imagem como que se assemelham, trabalhem os personagens como fotógrafos como escultores, como escritores ou como outras funções que não as de artistas. É o aspecto visual que provoca, inaugura o interdito e faz delirar a palavra já que

o que os sujeitos fazem ao experimentar algo esteticamente não é simplesmente "filtrar" os conteúdos de experiência presentificados pelo objeto por meio da sua própria existência (já constituída), pois não podem ignorar a organização significante interna dos objetos. A percepção estética coloca em jogo uma relação experimental entre a significação dos objetos estéticos e a nossa experiência presente, ao permitir fazermos uma experiência com as experiências presentificadas pelos objetos (GUIMARÃES, 2006, p. 16, grifo do autor).

O discurso literário de Tércia Montenegro igualmente inter-relaciona sentidos tendo a palavra como ambiente de tensão entre experiências. Por meio do texto verbal, sujeitos narram o que veem e o que não pode ser visto, tendo voz por meio de personagens que trabalham o duo escrita-visão em suas profissões ou hobbys. Os conflitos, os desenvolvimentos e os desfechos são quase sempre equiparados a imagens, construindo metáforas, comparações, e mesmo descrições pictóricas de sentimentos e ações. A trama passa a agir como uma conjunção de fotografias que se agrupam em unidades, os contos. Neles, os sentidos corporais do leitor também disputam por esta "experiência com as experiências presentificadas pelos objetos", como atesta Guimarães (2006, p. 16, grifo do autor).

Desse duelo, Manguel lança questões que cabem plenamente a este estudo: "Qualquer que seja o caso, as imagens, assim como as palavras, são a matéria de que somos feitos. Mas qualquer imagem pode ser lida? Ou, pelo menos, podemos criar uma leitura para qualquer imagem?" (2001, p. 21). A literatura se constitui como uma prática cultural humana que faz girar narrativas em torno daquele que observa e conta sobre/por meio do pensamento humano. Entretanto, "Qualquer imagem admite tradução em uma linguagem compreensível, revelando ao espectador aquilo que podemos chamar de Narrativa da imagem, com N maiúsculo?" (MANGUEL, 2001, p. 21), problematiza o teórico.
Concordando com ele, penso que as imagens têm tudo para se fazerem presenças constituídas por nossos anseios sendo participantes diretas de nossas experiências, e, muitas vezes, promotoras de afetos. No conto "A alma e o peso", de Tércia Montenegro, por exemplo, a narradora se inclina aos desejos de Leila, uma fotógrafa e fã, e depois de duas horas de sessão fotográfica, expõe os afetos que a situação artística lhe provocara:

Não tinha me maquiado para a sessão, mas entrei no apartamento com uma textura esquisita sobre o rosto. Era talvez uma película, criada por tantos disparos fotográficos - ou, quem sabe, era a justificativa da lenda que certos povos defendem, de que o retrato gasta a imagem da pessoa, corrói seu aspecto e, por fim, engole sua personalidade. Eu me sentia medo artificial, como se tivesse passado os últimos dias na pele de outra pessoa, usando roupas absurdas ou reproduzindo tiques ensaiados. No entanto, nada daquilo tinha acontecido - eu apenas me transformara num personagem de fotografia, emprestara minha aparência àquilo, mas não tinha me despregado de mim mesma. Pelo menos, foi o que repeti diversas vezes, naquela noite em que demorei a dormir (MONTENEGRO, 2012, p. 19).

No excerto, o exercício fotográfico é sentido e compreendido de diferentes maneiras. A narradora adere afetivamente às crenças mais atávicas do processo de captura da imagem e teme que foi capturada, mais do que em sua aparência, em sua ilusão de identidade. Susan Sontag em seu Sobre fotografia reflete sobre este tipo de crença ao dizer que "A fotografia é, de várias maneiras, uma aquisição. Em sua forma mais simples, temos numa foto uma posse vicária de uma pessoa ou de uma coisa querida, uma posse que dá às fotos um pouco do caráter próprio dos objetos únicos" (2004, p. 172). De tal forma, a personagem do conto elabora para si um discurso de emancipação da própria imagem ao se assegurar repetidamente que "apenas me transformara num personagem de fotografia, emprestara minha aparência àquilo, mas não tinha me despregado de mim mesma" (MONTENEGRO, 2012, p. 19).

Sontag também discorre sobre um segundo modo aquisitivo da fotografia. Para ela, "Por meio das fotos, temos também uma relação de consumidores com os eventos, tanto com os eventos que fazem parte de nossa experiência como com aqueles que dela não fazem parte" (SONTAG, 2004, p. 172). Tal é assim 
que, ao fim da narrativa, a protagonista do conto está certa de que verá "em cada foto a imagem de Leila, com a expressão asmática de um susto magoado e a voz interrompida por uma tragédia" (MONTENEGRO, 2012, p. 23). 0 visível instaura o acontecimento invisível, que se repete em cada nova experiência de observação, tendo o corpo como lugar por excelência de tal evento.

Entretanto, antes do final da narrativa, as personagens põem em questão a destruição de algo tão polifônico e interminável quanto o conto: as fotos. Percebendo o distanciamento da narradora frente às sugestões eróticas que promovera, Leila, a fotógrafa e obsessiva, sofre de um ataque e: "Numa única tarde, destruiu as duas câmeras fotográficas e liquidou o contrato do estúdio. Queimou os negativos que guardava numa caixa de bombons [...]" (MONTENEGRO, 2012, p. 22). Ela volta para a sua cidade natal e para a mãe que sofre de Alzheimer, constituindo um grupo de signos que dualizam lembrança e esquecimento, como aponta Barthes:

Eu queria, em suma, que minha imagem móbil, sacudida entre mil fotos variáveis, ao sabor das situações, das idades, coincidisse sempre com meu "eu" (profundo, como é sabido); mas é o contrário que é preciso dizer: sou "eu" que não coincido jamais com minha imagem; pois é a imagem que é pesada, imóvel, obstinada (por isso a sociedade se apoia nela), e sou "eu" que sou leve, dividido, disperso e que, como um ludião, não fico no lugar, agitando-me em meu frasco [...]" (BARTHES, 1984, p. 24).

A ideia de realidade se mostra, de tal forma, sempre destrutível. Em um universo de imagens, as permanências passam por um processo de fragmentação que diz fortemente a respeito de nosso tempo. Ainda assim, Barthes (1984) afirma a incapacidade de, por meio da fotografia ou de qualquer outro dispositivo - exceto o amor extremo, o da mãe - chegar-se ao "grau zero do corpo". Seguimos, assim, repletos de ditos e interditos. A contemporaneidade "desdiz" a palavra, quebra-a e inaugura novos dispositivos de desprendimento e de controle. Nos contos de Tércia Montenegro, segue-se um cortejo de tangenciamentos e capturas dos corpos inaugurados com os livros. Problematiza-se o enfraquecimento da escrita com a absorção de linguagens e técnicas imagéticas. A grafia mais do que falar, dá a ver e, assim, se fortalece em tempos de pós-verdade.

\section{A palavra da imagem}

Em “O lado imóvel", também do livro $O$ tempo em estado sólido, a mãe dialoga com o filho "'Preciso que você dê uma olhada nisso', falou, e abriu a caixa para retirar, uma por uma, várias fotografias. Cada imagem era a reprodução de um quadro" (MONTENEGRO, 2012, p. 63) e a criança começa uma caçada em um galpão alfandegário em busca de fazer justiça às obras de arte do pai, confiscadas pela polícia. Para conseguir reaver a sua própria verdade, "Era preciso reconhecer os quadros como se fossem pessoas, como desaparecidos cujo retrato se fixa nos postes e nos muros, com o valor da recompensa e o telefone de contato" (MONTENEGRO, 2012, p. 68). Mais do que nunca, aqui a imbricação sujeito-imagempalavra está presente tendo o fio do desejo como eixo do que Sontag (2004) chama de dossiê interminável de visualidades. Cabe à criança buscar o pai perdido em um depósito de interditos, tendo como auxílio apenas os sentidos. 0 imaginário, então, se retroalimenta a partir da tentativa de reprodução de uma gravura.

É preciso inocentar ou condenar o pai, "como um perigoso bandido que se procura, um extraviado perseguido por cidades inteiras - a fotografia amassada na mão, apresentada em lojas, farmácias, postos de gasolina: 'Já viu esse sujeito?'”, diz Montenegro (2012, p. 68). Após uma série de desafios, o menino encontra o seu objeto almejado e passa a tentar constituir uma narrativa própria a partir de tais fragmentos:

Eram de fato cinco telas, dava para saber no tato; se treinasse um pou co, podia até adivinhar as cores nas pontas dos dedos, embora ali tudo estivesse escuro e sombrio. Ele sabia que o pai pintava com bastante vermelho, e as saliências de tinta, os relevos das camadas ásperas, pareciam indicar certa violência cromática. 0 menino tentou puxar uma extremidade, achava que fosse o suficiente, mas o que viu não satisfazia. Pôs a tela no chão, desenrolou-a como um papiro, enquanto a prendia nos cantos com pacotes que estavam perto. Assim estendida, crucificada pelos quatro vértices, quis que fizesse algum sentido, formasse algum desenho ou paisagem (MONTENEGRO, 2012, p. 71).

0 papiro é, no trecho, metáfora do hibridismo entre a visão e a fala. Após ser bem-sucedido no reconhecimento tátil das cores e intensidades de traços do 
pai, a "violência cromática" não dá conta de preencher a demanda de sentido. É preciso abrir a tela como um todo, mais, crucificá-la, violentá-la. Só assim, invertidas as posições do par ativo-passivo, exibicionista-voyeur de Freud (2013), pode ser exequível algum tipo de construção de significado por meio, só e sempre, da própria imagem, em um "desenho ou paisagem". Ao fim do conto, o menino se ajoelha para melhor observar os detalhes (de si mesmo?) e é quando os guardas o interceptam. 0 interdito e a pulsão estão pungentes na narrativa. Por meio da descoberta, leitura e estudo sobre a imagem, o sujeito se dobra (ajoelhando-se até) para encarar o que lhe é imposto como diligência.

A construção do ato de ver é atividade sempre mútua nas noções clássica do fundador do inconsciente. Para Freud, todas as fases da pulsão de olhar "coexistem lado a lado, e tal suposição se torna evidente se tomamos por base não as ações da pulsão, mas o mecanismo para sua satisfação" (FREUD, 2013, p. 43). Outros contos de Tércia Montenegro relacionam libido, palavra e fotografia, trazendo primordialmente a atuação dos personagens como capturadores ou capturados visualmente enquanto ponto de conflito para a trama erótica a ser desenvolvida.

Em "Esboço de sangue e cinza" a narradora é uma fotógrafa (ou a fotógrafa é uma narradora?) e desenvolve uma descrição pictórica do seu objeto, Solano, no "modo como levava o cigarro no gesto suave, a brasa cintilando com o sopro sugado, a boca numa projeção de beijo. Então foram cliques e ângulos sucessivos, o coração afoito" (MONTENEGRO, 2012, p. 39). A personagem se entende unicamente enquanto observadora e pode dar fala ao que anseia: "quero capturar o seu perfil, seu descanso com os braços cruzados, a expressão distante, e quero aproveitar que não sou vista, meu reflexo se perde na escuridão espelhada em que estou [...]" (MONTENEGRO, 2012, p. 39).

Outra vez, o desejo mostra a sua ambivalência, revertendo a condição de ver e ser visto, mesclando o visível e o invisível da imagem e confirmando que o erotismo tem dupla face, como assegura Georges Didi-Huberman a quem "O que vemos só vale - só vive - em nossos olhos pelo que nos olha. Inelutável porém é a cisão que separa dentro de nós o que vemos daquilo que nos olha" (1998, p. 29). Os protagonistas da narrativa de Tércia encontram-se ao fim do conto e, após juntar às imagens as palavras que lhes apresentam um para o outro, viajam. "Desgeograficados", os personagens reaparecem no conto "Aquarela com bonsai" em que fazem um ménage à trois em algum país africano, atividade não bem- sucedida por parte da narradora que, presenciando e constituindo-se um veto ao prazer, elabora uma teoria do corpo enquanto máquina fotográfica:

Fazia parte do impulso que me marcava: como a saída repentina da casa de meus pais, o abandono da faculdade, a própria vinda para a África... isso tudo não era maluco? Resultado de uma pulsão instantânea como um flash, e agora eu sentia tanta falta de uma câmera. Se eu pudesse registrar, se eu me desse o papel de simples observadora - mesmo que fosse Solano e outra mulher, não importava. Participar era pior; eu queria ter uma função distante, continuar vestida naquele quarto, com a minha armadura, o meu tripé. Se houvesse fotografias, depois eu poderia me excitar em casa, sozinha. Mas tudo era impulso, imagem repentina, e a mulher se levantou (MONTENEGRO, 2012, p. 51).

A pulsão é um flash, o corpo é um tripé e o desejo é uma imagem repentina. Essa narradora quer a posição ativa na elaboração da palavra e da imagem, mas não nas suas construções enquanto participante. Ela rejeita a implicação do corpo no prazer e quer permanecer apenas na condição voyeur, fazendo do "sentir" nada além de um "ver". Durante o sexo a três, sente-se tal qual uma máquina, um objeto sem expressividade. 0 orgasmo só será advindo na solidão quando em casa, poderá se excitar sozinha com as imagens fantasiosas, sem a intervenção do que é repulsivo (o corpo de uma outra mulher) e solitário, abrindo-se largamente ao imaginário da solitude e da autossuficiência.

Também em Sobre a Fotografia, Susan Sontag analisa uma fotografia em que muitos corpos aparecem amalgamados com a exceção de um que quase sorri e vê que este tem uma câmera junto ao olho. A narrativa é extremamente similar ao conto de Tércia Montenegro em que "Enquanto os demais são espectadores passivos, nitidamente alarmados, ter uma câmera transformou uma pessoa em algo ativo, um voyeur, só ele dominou a situação. [...]" (SONTAG, 2004, p. 21). Ao intervir, em ambos os casos na composição do acontecimento, a câmera (hipotética ou real) promove o equilíbrio temporário entre os sujeitos e confirma uma vez mais a palavra da teórica que diz: "Tirar fotos estabeleceu uma relação voyeurística crônica com o mundo, que nivela o significado de todos os acontecimentos" (SONTAG, 2004, p. 21).

0 parceiro da narradora, Solano, como que capturando o desejo em sua observação, puxa a personagem para um abraço, solicitando-a na composição 
cênica-sexual. Percebendo-se presa à dinâmica em trio, a fotografia novamente aparece realocada: "Imaginei que a mulher, sim, era a fotógrafa, pronta para fazer o ensaio de um casal; não importava que estivesse nua e sem câmera. Ficasse distante, fotografando com o olhar, ou mesmo com qualquer coisa [...]" (MONTENEGRO, 2012, p. 51). Entretanto, não é de qualquer lugar que se obtém o registro da pulsão de ver pois, para a narradora, a metáfora do obturador tem um direcionamento específico: "aquela abertura que tivesse, caixa preta em que brilhava um brinco, gota de pérola presa ao clitóris. [...] Eu era um fantasma antigo que se espanta com um casal recente: Solano e sua nova amante, uma africana de corpo perfeito" (MONTENEGRO, 2012, p. 52).

Tornando um dispositivo do olhar a vagina da mulher negra tida como perfeita, a narradora, que segue sem nos dar seu nome, efetiva o receio de outras personagens de Tércia Montenegro, o de morrer ao se fazer imagem fotografada. Sem a sensação de morte que um gozo inexistente na cena traria, o sentimento fantasmagórico é derivado diretamente do ato de ser capturada pela visão. Um piercing no clitóris da negra é o próprio flash, o disparo de captura. Ao ser detectada pelo elemento corporal inóspito, a presa perde a sua subjetividade, morrendo como objeto. 0 corpo/a palavra padece diante da/sendo a imagem, e o presente narrativo vira lembrança, "um fantasma antigo" que divide os lençóis da cama e some mesmo entre eles.

A vagina, escura e observadora, é um zoom para a corporeidade da africana e compõe, aos olhos da narradora, uma paisagem. É, utilizando-me das palavras de Roland Barthes sobre o studium, "uma vastidão, ele tem a extensão de um campo, que percebo com bastante familiaridade em função de meu saber, de minha cultura [...] uma espécie de investimento geral, ardoroso, é verdade, mas sem acuidade particular" (1984, p. 44-45). 0 piercing, do contrário, é o que, na identificação ardorosa com o órgão sexual feminino, seria o punctum, a flecha que a atravessa, "essa ferida, essa picada, essa marca feita por um instrumento pontudo [...] pequeno buraco, pequena mancha, pequeno corte - e também lance de dados" (BARTHES, 1984, p. 46).

Entre ferir e ser ferido, dar luz na palavra ou na imagem, os personagens de Tércia se mantêm fotografando enquanto ato de pulsão de vida. Eles se agarram à máquina obturadora, carentes de si mesmos e de seus reflexos do/no outro. A próxima narradora fotógrafa parece buscar um alívio na visualidade e lembra, sozinha em casa, de uma época em que fotografava nuvens. Há inclusive um varal de fotografias em sua casa, mas agora nenhuma das imagens retrata o céu. 0 que retratam? Mistério, indizível... 0 nome do conto é, em si mesmo, uma teoria sobre a imagem/palavra: "Cartografia de instantes".

Nesta cartografia, Larissa, personagem também reincidente no livro $O$ tempo em estado sólido, tem as memórias visuais de seu amante no conto "Cada movimento seu": "O óbvio foi que pensasse nas fotografias e desde o começo quisesse enviá-las. Claro, as fotografias pulsavam do álbum como fantasmas, simulacros fragilmente presos" (MONTENEGRO, 2012, p. 82) As imagens estáticas e em vídeo das transas com Vitório se tornariam objeto de ardilosa vingança contra as perseguições da agora viúva do homem: "A mulher dissera para Larissa desaparecer, e é isso que ela agora planeja. Viajará por todos os locais que sempre desejou, levando as fotografias e também o vídeo [...] Aliás, o vídeo será a mais importante remessa do correio" (MONTENEGRO, 2012, p. 85).

Ao assistir às imagens, a personagem amplia "o que é limitado por uma moldura para um antes e um depois e, por meio da arte de narrar histórias (sejam de amor ou de ódio), conferimos à imagem imutável uma vida infinita" (MANGUEL, 2001, p. 27). 0 desejo, tal como os registros visuais, também não se esgota e permanece em cada movimento das imagens, é o próprio tema do texto, pois, como a personagem, conta: "Vitório estava sentado no sofá, num enquadramento cinza, e seu corpo também era meio cinzento, o calção quase prateado. Não houve risos constrangidos; ele parecia já acostumado a se tocar e enrijecer enquanto olhava a câmera" (MONTENEGRO, 2012, p. 83).

0 morto, assim, segue vivo. E, aos olhos das duas mulheres, cheio de pulsão libidinal. É alvo e flecha do ato erótico como uma fantasia sexual entre a câmera e o espectador, ainda que:

Se os fotógrafos profissionais têm, muitas vezes, fantasias sexuais quando estão atrás da câmera, talvez a perversão resida no fato de que essas fantasias sejam, ao mesmo tempo, plausíveis e muito impróprias. [...] Com efeito, usar uma câmera não é um modo muito bom de aproximar-se sexualmente de alguém. Entre o fotógrafo e seu tema, tem de haver distância. A câmera não estupra, nem mesmo possui, embora possa atrever-se, intrometer-se, atravessar, distorcer, explorar e, no extremo da metáfora, assassinar - todas essas atividades que, diferentemente do sexo propriamente dito, podem ser levadas a efeito à distância e com certa indiferença (SONTAG, 2004, p. 23). 
Tal distância entre o fotógrafo e o fotografado é uma indiferença que, na contramão do ato profissional da atividade artística, não é assumida nos contos para provocar justamente a tensão. É preciso que ocorra o ruído entre os participantes do ato pictórico, pois é nesta zona intervalar de comunicação que reside a barreira do desejo. Como que cientes dos "conselhos" teóricos de Sontag, os personagens de Tércia Montenegro permitem a si e ao outro "atrever-se, intrometer-se, atravessar, distorcer, explorar e, no extremo da metáfora, assassinar" (SONTAG, 2004, p. 23), fazendo a imagem conter mais do que um constructo, mas um afeto que segue pungente na lembrança, no gozo e na carência de ambas as coisas.

No conto "Exposição", a personagem-narradora inominada reconstrói em telas o rosto, o corpo e o ritmo da respiração de Alessandro, amante que perdera. Em uma nova tentativa de segurar o tempo que corre, a artista preserva as suas demandas não saciadas, mas, ao contrário de Larissa, que envia por correio as imagens dos fragmentos corpóreos de quem ama, esconde. As telas da personagem, incompletas, "empilham-se no quarto, cobertas por lençóis. É nessa ideia de castidade, de telas recolhidas sob panos, que penso agora [...]. Por que precisamos, no final das contas, mostrar? Um exibicionismo necessário à arte, uma questão de sobrevivência [...]" (MONTENEGRO, 2012, p. 87).

0 embate entre esconder e mostrar confirma a condição erótica do labor artístico nos contos. A palavra, então, surge para contar do que está encoberto? Ela dá conta de "revelar"? De que maneira é a imagem que desmente a palavra? É ela quem assoma, como a protagonista de "As paisagens" faz com o narrador na visita que ele faz às suas pinturas e fotografias em uma galeria, no intenso agora: "E estava assim, pensando diante da imagem gigantesca de um perfil canino, quando a criatura apareceu. [...] Na verdade, ela não apareceu exatamente; já estava lá, parada talvez há horas, mas eu só a enxerguei naquele instante [...]" (MONTENEGRO, 2012, p. 31).

A espécie de camuflagem à qual adere a personagem é explicada pelo acessório utilizado: uma máscara de cachorro, tornando-a semelhante aos animais que ela retrata nos quadros. Órfã e com os dois irmãos gêmeos tendo cometido suicídio juntos, a garota que o narrador até então conhecia e que ficava sempre próxima a um cão, com quem unicamente se sentia à vontade, torna-se mulher e uma artista legitimada. Ela está presente, "com uma cadeira ao lado, para quem quisesse se aproximar" (MONTENEGRO, 2012, p. 32). A associação aqui é entre o trecho do conto e a performance "O artista está presente" de Marina Abramovic, realizada em 2010 no Museu de Arte Moderna de Nova York.
"Por um instante, tive a sensação de que a voz vinha não da criatura sentada a meu lado, mas de um dos quadros" (MONTENEGRO, 2012, p. 32), diz o narrador que tenha dialogar com a personagem, ou com os seus artefatos, ou consigo mesmo... Enquanto tenta entender o que leva à escolha daquele tipo de abordagem, entende que vida e obra não se separam naquela dimensão psicológica e expressiva socialmente. Paulina, a performer não é só a adulta, nem a criança, é criadora e criatura, pois "as paredes de uma galeria estavam lá como muros estranhos e, quem sabe, hostis. Era preciso proteger as obras, dar-lhes um tipo de companhia ou familiaridade. 'Por que são os nossos filhos, entende?'” (MONTENEGRO, 2012, p. 33).

A união, entretanto, também se mostra insustentável, pois, ao fim do conto, a personagem tira a sua máscara e desfaz a barreira do desconhecido, instaurando-a na palavra delirante do narrador em busca da reconstrução psicológica da artista: "Não durou dois segundos aquela visão, logo me distanciei, sem fazer nenhum dos convites ou promessas que tinha imaginado" (MONTENEGRO, 2012, p. 35). 0 corpo não sustenta a crueza que transborda a palavra esperada? A imagem cala. Quem teme quem nesse conto?

Nessas histórias, o passado como o único tempo detentor de durabilidade está marcado pelas fotos. Elas documentam o ocorrido, já que para Comolli: "Não é tanto as imagens que faltam, mas as imagens que duram é que faltam" (2007, p. 128). 0 autor, que fala sobre cinema, contempla também a literatura, aquela que muitas vezes também tem horror ao vazio, como ele diz a respeito do "mundo filmado". Comolli ainda problematiza de forma contundente a relação entre palavra e imagem, declarando que é preciso que o corpo-leitor fale, seja erótico assim como o é na experiência do cinema, foco do teórico: "A fala filmada não é esperada como que nos diria alguma coisa da verdade do sujeito faltante, ela nos surge como uma das mentiras possíveis da escuta", confirma Comolli (2007, p. 133).

\section{Fotografias literárias}

Tércia Montenegro dá seguimento ao seu jogo de (des)identificações familiares tendo a imagem como conflito. A jovem mãe do conto "O resto de teu corpo no aquário", publicado no livro homônimo, vê a sua filha pela primeira vez entrecortada pela névoa do que já poderia anunciar a doença 
que a garota sofreria e pelas palavras do médico ao fazer o ultrassom. Começa, com o trecho abaixo, uma via crucis do corpo, para usar o termo que é título de obra de Clarice Lispector, em que as duas personagens se fragilizam até a fragmentação psicofísica a que o laço maternal, em cuidado e culpa, direciona:

Asteriscos brilhantes desenhavam na tela zonas mais intensas, compactando-se numa figura que podia ser humana. Minha primeira visão foi esta: algo manchado, bolando sem rosto dentro de mim e passando para o vídeo como um desenho infantil. Então o médico desfiou as palavras como quem puxa a linha solta de um bordado, e pensei que a vida era mesmo um tecido pronto, do tamanho exato, não restando mais nada, a não ser combinar cores e linhas em certos traços. Ainda podia decidir outro destino - era o que me dizias. Mas eu achava que seria tudo igual, no fundo: a existência de Clara já acontecera (MONTENEGRO, 1998, p. 63).

A narradora é uma resenhista de livros para o jornal; Clara, sua filha cujo corpo retorcido e em estado de inconsciência vai se mostrando, ao longo da narrativa, um empecilho à condição de vida daquela que a gerou. Da palavra, a comentarista de publicações passa a ter uma única imagem à mente, a da "criança anormal" (MONTENEGRO, 2005, p. 65) que concebera e que o dia a dia a transforma em nada além de "a escrava de uma criança. Alguém que já não se importava com vaidades. Uma jovem que não pensava em beleza, ao olhar-se no espelho; apenas reconhecia os cabelos loiros, as sobrancelhas finas - tudo igual à filha, o seu autorretrato da invalidez" (MONTENEGRO, 2005, p. 65-66).

As duas configuram, de tal forma, um duplo autodestrutivo. Para Edgar Morin (2015), a imagem é uma presença que mostra (e é mostrada) por seu oposto, uma ausência. É neste embate entre o que se vê e o que não, que surge o pensamento complexo, o desejo, o sujeito enfim. Nas duas personagens de Tércia, é possível notar que a objetividade e a subjetividade, tal como expõe Morin, estão imbricadas. 0 corpo nulo da filha ao mesmo tempo espelha diretamente a invalidez da mãe: "Alguma coisa deve ter ficado dentro de mim, algo que não tinha seguido em frente, para que Clara não nascesse perfeita. Olhava meu corpo, imaginando que um resquício ainda estaria lá [...]" (MONTENEGRO, 2005, p. 68).

No entanto, também o vazio dá a ver "até uma objetividade-subjetividade extrema ou alucinação" (MORIN, 2015, p. 29) quando a personagem assim descreve a filha, a si própria e ao elo monstruoso entre as duas personagens do conto fotográfico: "Na tela de ultrassonografia, o borrão azul significava uma vida. [...] Um universo de cegueira - o feto flutua nos limites da membrana, move-se pela tontura das águas, submerso no líquido amniótico. Foi quando vi o peixe-monstro dentro de um aquário" (MONTENEGRO, 2005, p. 68). A carência subjetiva adquire aqui um caráter surreal identificado pelo teórico, quando a imagem projeta, aliena, objetiva, alucina e fetichiza, pois: "o duplo concentra em si, como se aí se realizassem, todas as carências do indivíduo e, em primeiro lugar, o seu anseio mais loucamente subjetivo: a imortalidade" (MORIN, 2015, p. 30).

A maternidade, crença biológica e "divinal" impingida às mulheres, é posta em xeque no conto de Tércia Montenegro quando a mãe se vê tão morta quanto a filha que lhe veta o gozo de ser propriamente mãe, mulher, humana, por fim. O sintagma "Um pouco de carne vibrante em formação" (MONTENEGRO, 2005, p. 68) do conto caberia, assim, tanto para a mulher quanto para a criança que, absolutamente contraria o seu nome - Clara. Ela é a própria sombra que percorre as carências da narradora, transformando-se em um peixe-monstro. 0 aquário não é nada além do que o próprio corpo da detentora da palavra que padece, minuto a minuto, de ser imagem que "traz consigo a angústia e a libertação, a vitória sobre a morte e a vitória da morte" (MORIN, 2015, p. 33).

Em outros dois contos Tércia trabalha a temática da morte relacionando-a ao possível poder da fotografia. Em "Rua Madagascar" também do livro $O$ resto de teu corpo no aquário, a filha é um duplo completamente entregue às terras. Seu corpo é encontrado morto e leva a mãe a uma caçada por justiça. No cemitério onde busca informações, uma repetida visualidade não cessa de acompanhá-la, especialmente porque é reproduzida pelo possível assassino, por meio de flores, sob a lápide da jovem: "Uma delas, a do meio, estava com o talo partido, dobrado de tal jeito que a flor parecia uma cabeça caída, derreada sobre a haste. Senti um arrepio: era quase a posição em que minha filha foi fotografada" (MONTENEGRO, 2005, p. 106).

Ela lembra que "A foto da perícia mostrava uma cena marrom de pele e lama, o corpo de lado, dentro do bueiro" (MONTENEGRO, 2005, p. 106) e se mantém em estado de investigação entre os túmulos até detectar o homem que promove o gesto ritualístico e macabro. Mesmo trêmula, a mãe narradora (se) descreve fotograficamente: "me levanto do esconderijo, me aproximo, vejo o recorte de seu corpo de homem balançando em meus olhos como numa câmera desfocada, 
noto quando ele pressente meus passos e se volta" (MONTENEGRO, 2005, p. 108). Em um segundo, aquele que se torna alvo da visão, some. 0 visível, do contrário, permanece sem fim, tal como a dor da perda da protagonista e narradora.

Há no conto duas reproduções imagéticas. A da foto, que captura o cadáver da filha, e a do ritual com flores, promovido pelo assassino, que mimetiza a ação que ele já realizara e parece querer tornar eterna. Configuram-se, assim, ao menos três "distinções". A mãe se distingue da filha, da qual não sabia a rotina e agora não sabe os motivos da morte; a foto que dá a ver pistas e lacunas sobre o assassinato; e o ritual, que pode falar de um sadismo de quem o executa rotineiramente no cemitério, de um masoquismo materno em ver e de um semnúmero de possibilidades sobre a relação prévia da morta com esse homem.

Em cada uma dessas barreiras de interpretação, a imagem é ao mesmo tempo perfuração por meio de quem a faz e a observa. Imagens e coisas, como fala Nancy (2005), se distinguem, mas especialmente porque guardam em si diferentes potências para o olhar que se transforma (ou não) em palavra, em significado. Posto fora e diante dos olhos, o visível nos prende, como a essa mãe:

Mas, o que se distingue essencialmente da coisa é a força, ou a energia, o empuxo, a intensidade. 0 "sagrado" sempre foi uma força, até mesmo uma violência. 0 que deve ser compreendido é o modo como a força e a imagem pertencem uma à outra inclusive na distinção, como a imagem se oferece através de um traço distintivo (toda imagem se declara ou indica-se "imagem" de alguma maneira) e como aquilo que ela oferece é, antes de tudo, uma força, uma intensidade, a própria força de sua distinção (NANCY, 2005, p. 98).

É nessa intensa força distintiva que, como fala o filósofo, faz com quem a imagem se apresente, convocando-nos enquanto seus leitores. As imagens parecem agenciar o olhar e seguem sendo sombra mais que luz. É exatamente no ato distintivo frente à coisa "representada" e aos sujeitos videntes que a imagem se encontra na arte. Na literatura, ela encontra um modo de ser manipulada em prol da potência de cisão da própria palavra narrada "tanto porque ela se furta à significação ou à definição, quanto porque ela pode ameaçar a si própria e destruir, nela mesma, as imagens de si, caso estas sejam imobilizadas em um código significante e em uma beleza assegurada" (NANCY, 2005, p. 108).
A violência de existir é, nos contos de Tércia Montenegro, a violência de, sobretudo, enxergar. Tudo se fragmenta e padece, exceto na observação em prol da memória e de si mesmo, por um fio. Distinguir-se, pois "Clara e distinta, a imagem é uma evidência. Ela é a evidência do distinto, sua própria distinção. Não há imagem a não ser quando há essa evidência; senão, há decoração ou ilustração, isto é, suporte de uma significação" (NANCY, 2005, p.107).

Com a palavra, portanto, a imagem em seu devir-sombra, não complementa, não decora, não cria laços. Ela parece romper, conflituar e ganhar voz conseguindo, como diz Nancy, "tocar a presença invisível do distinto, a distinção de sua presença" (2005, p.1 07). Também por isso, A literatura é, uma arte visual" (MONTENEGRO, [2015b]), como diz a escritora e, na contemporaneidade, isso reverbera ainda mais quando a sugestão e a incerteza tomam o espaço da verossimilhança que a palavra poderia dar conta, mas perde de forma crescente, como fala Foucault:

Não que a palavra seja imperfeita e esteja, em face do visível, num déficit que em vão se esforçaria por recuperar. São irredutíveis uma ao outro: por mais que se diga o que se vê, o que se vê não se aloja jamais no que se diz, e por mais que se faça ver o que se está dizendo por imagens, metáforas, comparações, o lugar onde estas resplandecem não é aquele que os olhos descortinam, mas aquele que as sucessões da sintaxe definem. Ora o nome próprio, nesse jogo, não passa de um artifício: permite mostrar com o dedo, quer dizer, fazer passar sub-repticiamente do espaço onde se fala para o espaço onde se olha, isto é, ajustá-los comodamente um sobre o outro como se fossem adequados. Mas, se se quiser manter aberta a relação entre a linguagem e o visível, se se quiser falar não de encontro a, mas a partir de sua incompatibilidade, de maneira que se permaneça o mais próximo possível de uma e de outro, é preciso então pôr de parte os nomes próprios e meter-se no infinito da tarefa (FOUCAULT, 2000, p. 26)

O encontro proposto por Foucault, de falar a partir da incompatibilidade, é a união instantânea e problemática entre palavra e imagem. Não há amálgama quando se pretende uma correspondência entre o que se diz e o que se faz ver. É nesse embate sem fim que os contos atuam, tendo a palavra em sentido de foto e a foto em forma de palavra como adversários-amantes. Tércia Montenegro combate nessa luta, por fim, também com suas palavras enquanto crítica, para comentar a visualidade literária. Fala, talvez, de uma teoria para 
a literatura que executa, além de enxergá-la como uma generalidade às artes: "A biblioteca da minha infância, com suas múltiplas cores verticais, plantou-me para sempre o gosto por mosaicos, vitrais, colchas de retalho, caleidoscópios, tudo o que mistura tonalidades" (MONTENEGRO, [2015b]).

As cores, os sons e as texturas das letras atestam, para a autora o desejo, a dor e a insistência na escrita/leitura também como um mecanismo de resiliência algo corporal, pois a literatura "É um pulsar que se regula individualmente, detém-se no desenho das letras, aprecia as manchas gráficas: em cada palavra vejo um laço. E nunca me protejo" (MONTENEGRO, [2015b]). A fala da escritora vai, assim, ao encontro da de Nancy, para quem a imagem é "variação singular da totalidade do sentido distinto" (2005, p. 108). Como o livro de areia de Borges, palavra e imagem se impõem contra a finitude e a ideia de significado. A fotografia é ao mesmo tempo substância e metáfora para os contos da autora cujo realismo descritivo deixa brechas para múltiplas imagens, sem perder o registro lírico do cotidiano.

Os contos de Tércia Montenegro, por mais conclusivos que pareçam ser verbalmente, extrapolam a si mesmos ao dar capacidade de significação às imagens que carregam. "Esse sentido é infinito, e cada variação é ela - mesma singularmente infinita. Cada imagem é um desvio finito do sentido infinito, cujo infinito é comprovado justo por esse desvio, pelo traço da distinção" (NANCY, 2005, p. 108), diz o filósofo por fim. Mas o fim, transgressor e poético, não chega, jazendo nas fotos e nas palavras de uma escritora de contos (in) visíveis, em linguagem descritiva-pictórica, em seus personagens fotógrafos e na presença da arte fotográfica como elemento conflitante às narrativas.

\section{Referências}

BARTHES, Roland. A câmera clara. 2. ed. Tradução de Júlio Castañon Guimarães. Rio de Janeiro: Nova Fronteira, 2015.

CORTÁZAR, Julio. Valise de cronópio. 2. ed. Tradução de Davi Arrigucci Jr. e João Alexandre Barbosa. São Paulo: Perspectiva, 2013.

DIDI-HUBERMAN, Georges. O que vemos, o que nos olha. Tradução de Paulo Neves. São Paulo: Editora 34, 1998.

FOUCAULT, Michel. As meninas. In: FOUCAULT, Michel. As palavras e as coisas. Tradução de Salma Tannus Muchail. São Paulo: Martins Fontes, 2000.

FREUD, Sigmund. As pulsões e seus destinos. 2. ed. Tradução de Pedro Heliodoro Tavares. Belo Horizonte: Autêntica, 2013.

GUIMARÃES, César. "O que ainda podemos esperar da Experiência Estética”. In: GUIMARÃES César; LEAL, Bruno Souza; MENDONÇA, Carlos Camargos (org.). Comunicação e experiência estética. Belo Horizonte: UFMG, 2006.

MANGUEL, Alberto. 0 espectador comum: a imagem como narrativa. In: MANGUEL, Alberto. Lendo imagens. Tradução de Rubens Figueiredo, Eichmberg Rosaura e Cláudia Straugh. São Paulo: Companhia das Letras, 2001.

MONTENEGRO, Tércia. O vendedor de Judas. Fortaleza: Edições UFC, 1998.

MONTENEGRO, Tércia. Linha férrea. São Paulo: Lemos Editorial, 2001.

MONTENEGRO, Tércia. O resto de teu corpo no aquário. Fortaleza: Secretaria de Cultura, 2005

MONTENEGRO, Tércia. O tempo em estado sólido. São Paulo: Grua, 2012a.

MONTENEGRO, Tércia. Os espantos. Fortaleza: Edições Demócrito Rocha, 2012b.

MONTEnEGRo, Tércia. Um gesto raro. Jornal de Biblioteca Pública do Paraná, Curitiba, [2015]. Disponível em: http://www.candido.bpp.pr.gov.br/modules/conteudo/conteudo. php?conteudo=316. Acesso em: 4 jan. 2019.

MONTENEGRO, Tércia. A literatura é uma arte visual. [São Paulo]: Blog da Companhia das Letras, 2015b. Disponível em: http://historico.blogdacompanhia.com.br/2015/04/a-literaturae-uma-arte-visual/ Acesso em: 4 jan. 2019. 
MORIN, Edgar. 0 encanto da imagem. In: MORIN, Edgar. $O$ cinema ou o homem imaginário. Tradução de Luciano Loprete. Lisboa: É Realizações, 2014.

NANCY, Jean-Luc. The image: the distinct. In: NANCY, Jean-Luc. The ground of image. Tradução de Carlos Eduardo Schmidt Capela. New York: Perspectives of Continenal Philosophy, 2005.

SCHØLLHAMMER, Karl Erik. Ficção brasileira contemporânea. Rio de Janeiro: Civilização Brasileira, 2011

SONTAG, Susan. Sobre fotografia. Tradução de Rubens Figueiredo. São Paulo: Companhia das Letras, 2004 